\title{
EFFECTS OF FERMENTATION AND HEATING ON THE FUNCTIONAL PROPERTIES OF PROCESSED FLOUR FROM AFRICAN OIL BEAN (Pentaclethra macrophylla benth) SEEDS
}

\section{Osagie-Eweka ESD $^{1 *}$ and TH Alaiya ${ }^{1}$}

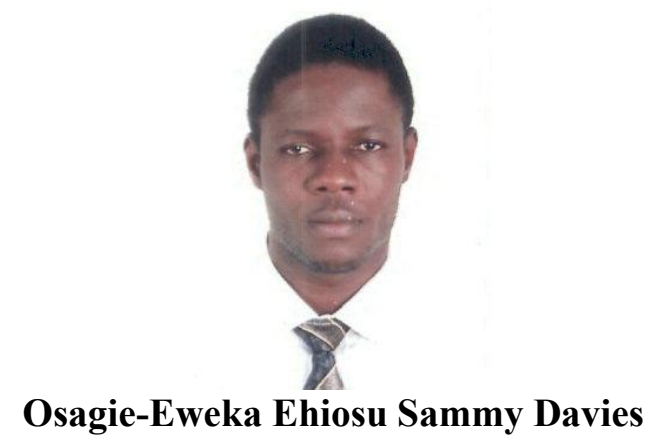

*Corresponding author's email: Osagieewekadavies@yahoo.co.uk

${ }^{1}$ Department of Biochemistry, Ambrose Alli University, Ekpoma, Edo State. Nigeria. 


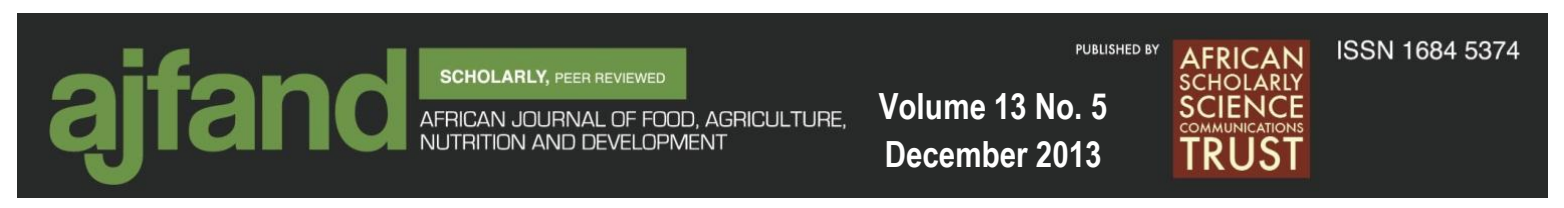

\begin{abstract}
A comparative study was conducted to determine the effects of heat treatment and fermentation on the functional properties of African oil bean (Pentaclethra macrophylla: Benth) seeds. The objective was to determine the nutritional benefits inherent therein, and the possible utilization of this plant food source as a complement in food formulation and improvement. The bean seed was broken to obtain the cotyledon, locally processed by fermentation and heat treatment, after which it was milled to obtain flour from the African oil bean. The control group of day 0 was not subjected to fermentation, but heat-treated and all other experimental groups (Day 17) subjected to fermentation and heating. The following selected physio-chemical properties were analyzed for the African oil bean seeds: water absorption capacity, oil absorption capacity and bulk densities were determined; the emulsion capacity and whipping ability were also determined. The oil absorption capacity ranged from $0.66-$ $1.26 \mathrm{~g} / \mathrm{ml}$; water absorption capacity, 0.76-1.32 g/ml; emulsion capacity, 33.33-64.67 $\mathrm{g} / \mathrm{ml}$, emulsion stability after one hour, $6.00-63.33 \mathrm{~g} / \mathrm{ml}$, bulk density, $0.40-0.49 \mathrm{~g} / \mathrm{g}$ and whipping ability, $0.00-0.93 \mathrm{~g} / \mathrm{ml}$. The processing methods adopted (fermentation and heating) to improve on the functional properties of the African oil bean seeds significantly affected $(p<0.05)$ the bulk density, whipping ability, emulsion stability and Stability after one hour of experimental samples fermented and heat treated (Day 1-7) compared to the Day 0 sample that was only heated while there was, however, no statistical significance recorded for the oil absorption capacity and water absorption capacity in experimental Day 1-7 compared to the control (Day 0). The treatment, demonstrated improved functional properties of the African Oil bean seeds; likely to enhance the palatability of formulated foods. The treatment did not show significant improvement on the oil absorption capacity and water absorption capacity of the bean; however, there was enhanced oil and water functionality.
\end{abstract}

Key words: Oil bean, Ugba, fermentation, heating 


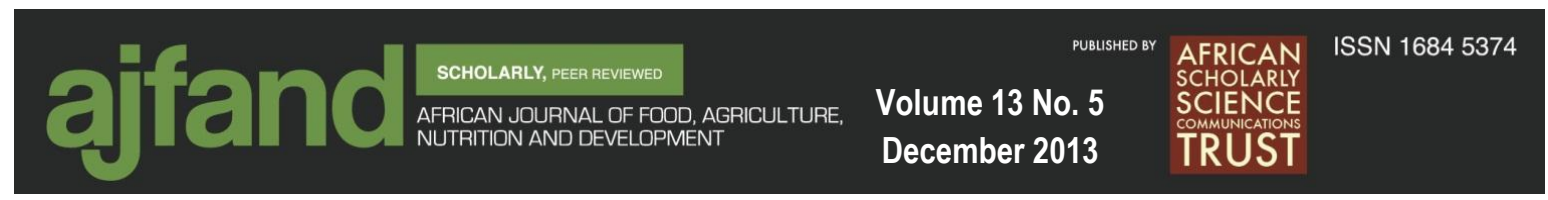

\section{INTRODUCTION}

The African oil bean seed (Pentaclethra macrophylla: Benth) is a popular tropical tree plant in Nigeria, locally called "UGBA" in the eastern part. It belongs to the family leguminosae and sub-family mimosoidae $[1,2]$. It is native to tropical Africa; the tree grows to a height of $21 \mathrm{~m}$ (13). Its well branched leaves form a canopy-like shape. It is often found in the southern rain forest zone of West Africa where it grows wild. The fruit is a long green pod which darkens as it matures. It is $36-46 \mathrm{~cm}$ long, 5-10 $\mathrm{cm}$ broad, and each pod contains up to 10 seeds (13). The seeds are hard and smooth in texture, brown in colour, endosperm white in colour and the seeds are about $6 \mathrm{~cm}$ long [3]. The Africa oil bean (seeds) is often used to complement carbohydrate foods, vegetables, and other foods in eastern Nigeria because it is known to contain a high proportion of protein and the 20 amino acids [1]. The oil bean seed is used to supply adequate essential amino acids (protein) needed in diets. Not only that, the oil bean seed contains high quantity and quality protein, it also contains $77-78 \%$ unsaturated and $22-33 \%$ saturated fatty acids $[4,5]$. The African oil bean seed is normally boiled for up to 12 hours or more to remove the hard seed coat. Following the removal of the seed coat, the cotyledon is sliced into smaller pieces and subjected to further boiling for a couple of hours. The sliced seeds are washed in water four to five times to reduce/remove the bitter taste of the seeds. The washed sliced 'UGBA' is further locally processed by wrapping small quantities in banana leaf and left to ferment for about 3 days or more as required at room temperature [6]. The African oil bean has attracted research interest due to its enormous food potential [7]. In addition, due to the fact that the functional properties considered in this work are attributable to the aforementioned nutrients, this research was designed to investigate the effects of fermentation and heat treatment on the functional properties of the flours obtained from African oil bean. It is, however, evident from research that improved physiochemical properties of plant materials can affect the behaviour of food system during preparation, processing, storage and utilization [2].

\section{MATERIALS AND METHODS}

\section{Sample Preparation}

The African oil bean was purchased from a local market in Aba, Abia State, Nigeria and transported to the Department of Biochemistry, Ambrose Alli University, Ekpoma, Edo State. The purchased sample was divided into 8 portions of $800 \mathrm{~g}$ each. The seeds in each of the portions were broken to collect the cotyledons and then placed in separate beakers. The beakers were thereafter labelled Day 0 - 7. The contents of these beakers were subjected to traditional fermentation in water [6]. The Day 0 sample was taken as the control (raw) sample. Day 1 sample was removed from water after 24 hour, oven dried at $100^{\circ} \mathrm{C}$ for 24 hours. The oven dried samples were milled to pass through a $20 \mathrm{~mm}$ sieve using a hammer mill. Day 2, 3, - 7, were harvested and treated similarly after 48, 72, and 168 hours, respectively. The flours obtained were stored in appropriately labelled air-tight containers until required for analyses. 


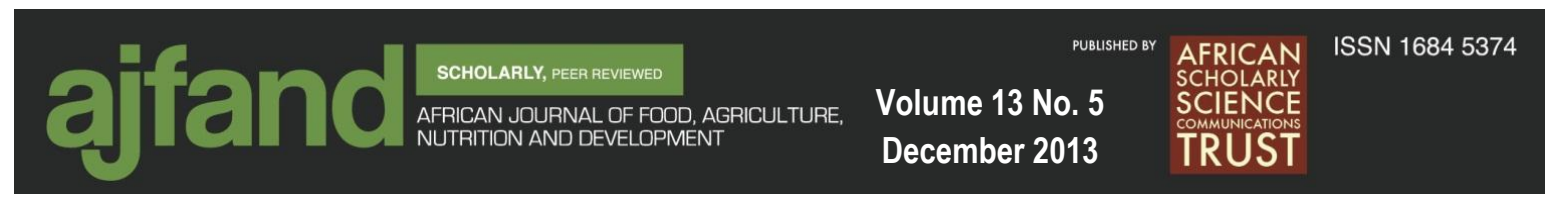

\section{Determination of Functional Properties}

Oil absorption capacity: weighed $2 \mathrm{~g}$ of milled sample (Pentaclethra macrophylla: Benth) was mixed with $5 \mathrm{ml}$ of pure soy oil (containing $58 \%$ polyunsaturated fatty acids, 29\% monounsaturated fatty acids, and 13\% saturated fatty acids) (15) in centrifuge tubes and allowed to stand for $30 \mathrm{~min}$ at ambient (room) temperature, then centrifuged at $2000 \mathrm{rpm}$ for $30 \mathrm{~min}$ and decanted. Water absorption capacity: weighed $2 \mathrm{~g}$ of milled sample (Pentaclethra macrophylla: Benth) was mixed with $5 \mathrm{ml}$ of distilled water in a test tube; the samples were centrifuged at $2000 \mathrm{rpm}$ for $30 \mathrm{~min}$ and decanted to remove excess water. Bulk density: without weighing sample, $10 \mathrm{mls}$ of sample was measured using a $10 \mathrm{ml}$ calibrated glass cylinder, the measuring cylinders containing the samples were fixed to a mechanical shaker and operated for 20 min to obtain fixed volumes that remain unchanged as described by Onimawo and Akubor [8]. Whipping Ability: was conducted by adding $50 \mathrm{ml}$ of distilled water to 3 g of Pentaclethra macrophylla: Benth (sample) in a blender and whipped for $1 \mathrm{~min}$. The resulting mixture was poured into a measuring cylinder and the volume of foam was recorded within $20 \mathrm{sec}$ and Emulsion capacity: $50 \mathrm{ml}$ of water was added to a measuring cylinder containing $30 \mathrm{ml}$ of pure soya oil and a $3 \mathrm{~g}$ of milled Pentaclethra macrophylla: Benth was added to the mixture in the cylinder. The entire mixture was centrifuged for $1 \mathrm{~min}$. at $3000 \mathrm{rpm}$ as described by Yatsumatsu et al. [9].

\section{DATA ANALYSES}

Microsoft ${ }^{\circledR}$ SPSS 16.0 was used to determine the mean and standard error of mean (SEM) of the triplicate results obtained from the raw data analyses of the various functional parameters of the African oil bean seeds; the One-way Analysis of Variance using the Tukey-Kramer was utilized in the multiple comparison statistical evaluation of data obtained from this study.

\section{RESULTS}

The results of some functional properties presented in table 1 show as follows: that the samples days 0 to 7 (control and experimental groups) subjected to heat, fermentation and heat treatment, respectively did not significantly affect the oil and water absorption capacities of African oil bean (Pentaclethra macrophylla: Benth) seed flour and thus did not show significant statistical comparison owing to the values of their mean and SEM. Although Day $3(1.26 \pm 0.09 \mathrm{~g} / \mathrm{mL})$ and Day $6(0.66 \pm 0.14$ $\mathrm{g} / \mathrm{mL})$ recorded the highest and least OAC while Day $1(1.32 \pm 0.17 \mathrm{~g} / \mathrm{mL})$ and Day 6 $(0.76 \pm 0.12 \mathrm{~g} / \mathrm{mL})$ recorded the highest and least WAC, respectively. There were, however changes observed in the oil and water absorption capacities of the respective days of heat treatment and fermentation, but did not show notable significant differences. Emulsion Capacity: sample fermented and heated for Day 2 (64.67 \pm $0.67 \mathrm{~g} / \mathrm{mL})$ recorded the highest and most significant $(\mathrm{P}<0.01)$ emulsion capacity compared to Day $0(33.33 \pm 0.88 \mathrm{~g} / \mathrm{mL})(\mathrm{Control})$. The least non-significant $(\mathrm{P}>0.05)$ emulsion capacity was observed in Day $3(29.67 \pm 0.33 \mathrm{~g} / \mathrm{mL})$. Emulsion stability after an hour: the stability after 1 hour was observed to be highly significant $(\mathrm{P}<0.001)$ in Day $2(63.33 \pm 0.33 \mathrm{~g} / \mathrm{mL})$ and $5(60.67 \pm 13.33 \mathrm{~g} / \mathrm{mL})$ samples when 


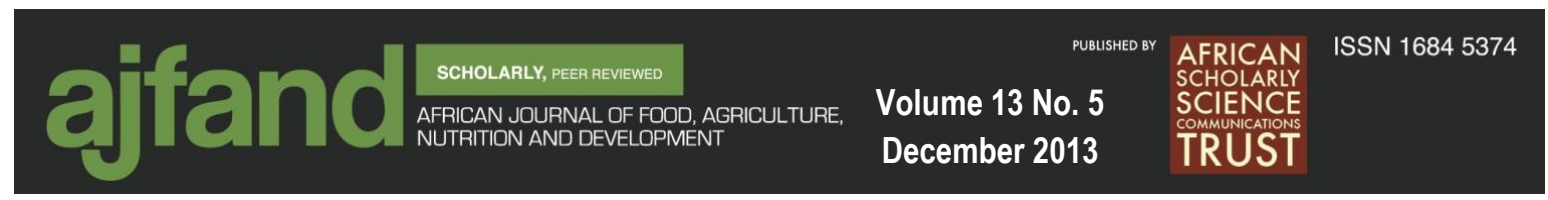

compared with Day $0(14.67 \pm 0.33 \mathrm{~g} / \mathrm{mL})$. Day 3 recorded the least non-significant $(\mathrm{P}>0.05)$ emulsion stability after 1 hour. Bulk Density: Day $2(0.40 \pm 0.01 \mathrm{~g} / \mathrm{g})$ and 5 $(0.42 \pm 0.01 \mathrm{~g} / \mathrm{g})$ samples recorded significantly $(\mathrm{P}<0.001)$, the highest bulk density when compared with the Day $0(0.49 \pm 0.00 \mathrm{~g} / \mathrm{g})$ sample. Although, a significant $(\mathrm{P}<0.05)$ increase in bulk density was recorded in Day $1(0.49 \pm 0.00 \mathrm{~g} / \mathrm{g})$ sample and Day $6(0.43 \pm 0.00 \mathrm{~g} / \mathrm{g})$ sample also recorded a significant change $(\mathrm{P}<0.01)$. The Day $3(0.47 \pm 0.00 \mathrm{~g} / \mathrm{g}), 4(0.45 \pm 0.00 \mathrm{~g} / \mathrm{g})$ and $7(0.45 \pm 0.00 \mathrm{~g} / \mathrm{g})$ bulk densities were non-significantly affected $(\mathrm{P}>0.05)$. Whipping Ability: The whipping ability of Day $1(0.93 \pm 0.03 \mathrm{~g} / \mathrm{mL})$ through to Day $7(0.93 \pm 0.03 \mathrm{~g} / \mathrm{mL})$ samples recorded significant differences $(\mathrm{P}<0.001)$ compared to the control Day $0(0.00 \pm 0.00)$.

\section{DISCUSSION}

The amino acid composition of the African oil bean seed having been reported by Achinewhu [1] is evident that it is a protein-rich plant food. The increased values recorded in the samples of days 7, 2, 4 and 3 as against the control (heated) sample of Day 0 for oil absorption capacity (table 1) suggests that fermentation and heat treatment enhanced the oil absorption capacity due to exposed non-polar amino acid residues which of course causes the protein to bind fats [8] making days 7, 2, 4 and 3 samples more suitable for industrial food formulation that increase mouth feel, flavor, texture extra of products. Samples of Day 1, 5 and 6 are observed to be undesirable in formulation of foods like pancakes, soups and other baked foods as these cannot bind fats to create tenderness or smoothness probably because the hydrophobic non-polar amino acids residues are not exposed enough to bind fats.

Water absorption is beneficial in baked products (bread) as it enhances expressible juice or cooking loss [10]. A research publication has revealed that water absorbed $\left(\mathrm{a}_{\mathrm{w}}\right)$ reduces browning in baked products, which promotes food digestibility and utilization; it also enhances dilution of reacting substances as a result of high bound water activity [11]. Increased water uptake observed in Day 1, 3, 4 and 7 of the WAC in table 1 revealed the existence of intra-molecular expansion in such food materials; it also suggests a high viscosity and stronger intra-molecular repulsive forces of sourced protein [12].

The reduced emulsion activity noticed in day 3 is undesirable in products like sausages, bologna, soup, and cakes [10]. It is, however, beneficial if sourced in the formulation of instant foods. The emulsion capacity of day 2 sample simulates enhanced emulsification activity and reduction of disulfide bonds with mecaptoethanol, which makes it suitable in making cake batters, mayonnaise and salad dressing among others.

The high stable emulsion activity observed in days 5 and 2 after one hour suggests its suitability in the formulation of sausage foods [10].

The low bulk density recorded in day 2 makes the sample a desirable formula in the industrial production of complementary foods like noodles, spaghetti, as well influence food packaging [8]. 


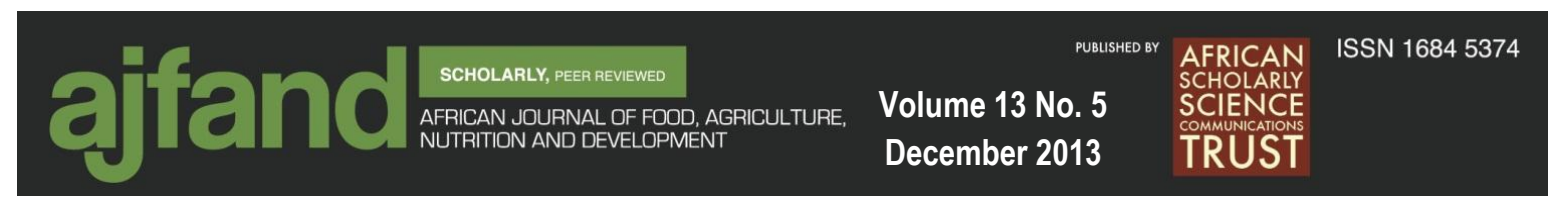

The high whippability recorded in days 1 and 7 indicated a non-flexible protein molecule (9) characteristic unable to reduce surface tension property and give good foam as a result of heat treatment (denaturation), which makes this food material a completely undesirable formula in making baked confectionaries, ice cream and food desert flavors.

\section{CONCLUSION}

In order to fully obtain the nutritive potentials of the African oil bean, the processing methods utilized should be carefully controlled for optimized results. The heat treatment could not have contributed to the enhanced selected functional properties considered in this study; however, the period of fermentation is suggested to be responsible for the improved functional properties of the African oil bean seed plant as presented in table 1 . The fact that the seed plant has been previously reported to possess much desired plant protein with numerous non-essential and essential amino acids [13] and some vitamin content [14] which conclusively makes the African oil bean seed useful in industrial food formulation and processing. 


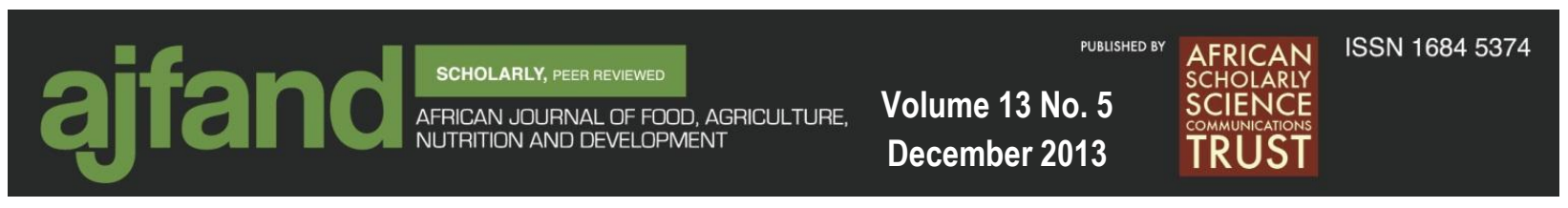

Table1: Functional properties of fermented and heat-processed African oil bean seed

$\begin{array}{ccccccc}\text { Day } & \text { Oil Absorption } & \text { Water Absorption } & \text { Emulsion Capacity } & \text { Emulsion } & \text { Bulk Density } & \text { Whippability } \\ & \text { Capacity }(\mathrm{OAC})(\mathrm{g} / \mathrm{mL}) & \text { Capacity }(\mathrm{WAC})(\mathrm{g} / \mathrm{mL}) & (\mathrm{EC})(\mathrm{g} / \mathrm{mL}) & \text { Stability/Hour }(\mathrm{g} / \mathrm{mL}) & (\mathrm{BD})(\mathrm{g} / \mathrm{g}) & (\mathrm{g} / \mathrm{mL}) \\ 0 & 0.84 \pm 0.23 & 0.94 \pm 0.15 & 33.33 \pm 0.88 & 14.67 \pm 0.33 & 0.47 \pm 0.00 & 0.00 \pm 0.00 \\ 1 & 0.83 \pm 0.21 & 1.32 \pm 0.17 & 34.67 \pm 0.33 & 7.67 \pm 0.67 & 0.49 \pm 0.00 & 0.93 \pm 0.03 \\ 2 & 0.99 \pm 0.28 & 0.93 \pm 0.16 & 64.67 \pm 0.67 & 63.33 \pm 0.33 & 0.40 \pm 0.01 & 0.90 \pm 0.00 \\ 3 & 1.26 \pm 0.09 & 1.20 \pm 0.20 & 29.67 \pm 0.33 & 6.00 \pm 0.58 & 0.47 \pm 0.00 & 0.90 \pm 0.00 \\ 4 & 1.03 \pm 0.06 & 1.12 \pm 0.11 & 33.33 \pm 0.67 & 29.33 \pm 0.67 & 0.45 \pm 0.00 & 0.87 \pm 0.06 \\ 5 & 0.78 \pm 0.04 & 0.98 \pm 0.16 & 47.33 \pm 12.84 & 60.67 \pm 13.33 & 0.42 \pm 0.01 & 0.90 \pm 0.00 \\ 6 & 0.66 \pm 0.14 & 0.76 \pm 0.12 & 36.67 \pm 0.33 & 8.67 \pm 0.33 & 0.43 \pm 0.00 & 0.80 \pm 0.00 \\ 7 & 0.94 \pm 0.18 & 1.19 \pm 0.18 & 37.33 \pm 0.33 & 16.67 \pm 0.33 & 0.45 \pm 0.00 & 0.93 \pm 0.03\end{array}$

Mean \pm SEM of triplicate samples 


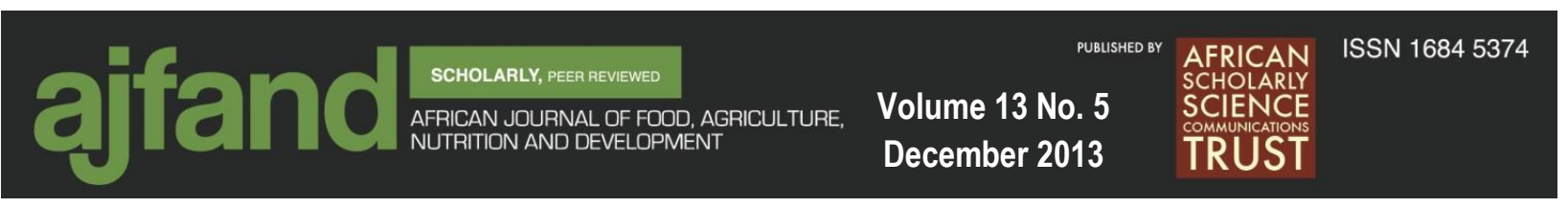

\section{REFERENCES}

1. Achinewhu SC Protein quality of African oil bean seed (Pentaclethra macrophylla: Benth). J of food sci. 1983; 48: 1374-1375.

2. Enujiugha VN and CT Akanbi Compositional changes of African oil bean (Pentaclethra macrophylla: Benth) seeds during thermal processing. Pak. J. of Nutri. 2005; 4(1): 27-31.

3. Enujiugha VN Nutrient changes during the fermentation of African oil bean (Pentaclethra macrophylla Benth) seed. Pak. J. of Nutri. 2003; 2(5): 320-323.

4. Achinewhu SC Composition and food potential of African oil bean seed (Pentaclethra macrophylla Benth) and Velvet bean (Mucuna urines). J. of Food Sci. 1982; 47: 17361737.

5. Enujuigha UM and JO Agbede Nutritional and anti-nutritional characteristics of African oil bean Pentaclethra macrophylla Benth seeds. Appl. of Trop. Agri. 2000; 5:1-4.

6. Achinewhu SC The effect of fermentation on carbohydrate and fatty acids Composition of the African oil bean (Pentaclethra macrophylla: Benth). Food chem. 1986; 19(2): 105-116.

7. Osagie AU and OU Eka Nuts and seeds. In: Osagie AU $1^{\text {st }}$ (ed). Nutritional quality of plant foods. Nigeria: Ambik press, 1998: 134-159.

8. Onimawo IA and PI Akubor Functional Properties. In: Onimawo IA and PI Akubor $1^{\text {st }}$ (ed). Food chemistry (integrated approach with biochemistry background). Nigeria: Ambik Press, 2005: 208-215.

9. Yatsumatsu K, Sawada K, Moritoka S, Misak M, Toda J, Wada T and I Ishii Whipping and emulsifying properties of soy bean products. J. of Agric and Biol. chem. 1972; 36: 719-727.

10. Schnepf $\mathbf{M}$ Protein-water interaction. In: Schnepf M $1^{\text {st }}$ (ed). Water and food quality. London: Elsevier Applied science, 1989: 135-168.

11. Eichner $\mathbf{K}$ and $\mathbf{M}$ Ciner-Doruk Formation and decomposition of browning intermediates and visible sugar-amine browning reactions in water activity. In: Rockland L and G Steward $1^{\text {st }}(\mathrm{ed})$. Influences of food. New York: Academic Press, 1975: 567603.

12. Urbanski G, Wei L, Nelson A and G Steinberg Rheology models for pseudoplastic soy system based on water binding. J. Of Food Sci. 1983; 48: 1436-1439. 


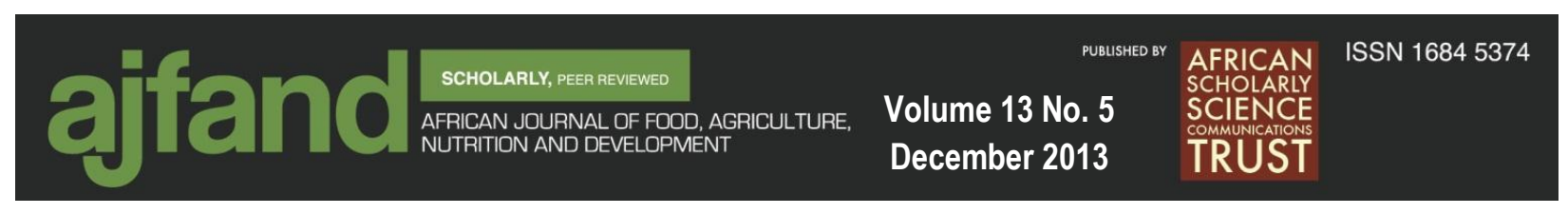

13. Ikhuoria EU, Aiwonegbe AE, Okoli $\mathbf{P}$ and $M$ Idu Characteristics and Composition of African Oil Bean Seed (Pentaclethra macrophylla Benth). J. of Appl Sci. 2008; 8(7): 1337-1339.

14. Achinewhu SC and $\mathbf{J}$ Ryley Effect of fermentation on thiamine, riboflavin and niacin content of Melon seed (Citrullus vulgaris) and African oil bean seed (Pentaclethra macrophylla Benth). Food chem. 1986; 20: 243-252.

15. Grand cereals and Oil Limited. Batch number: 0091006. www.grandcereals.com. Accessed April, 2009. 